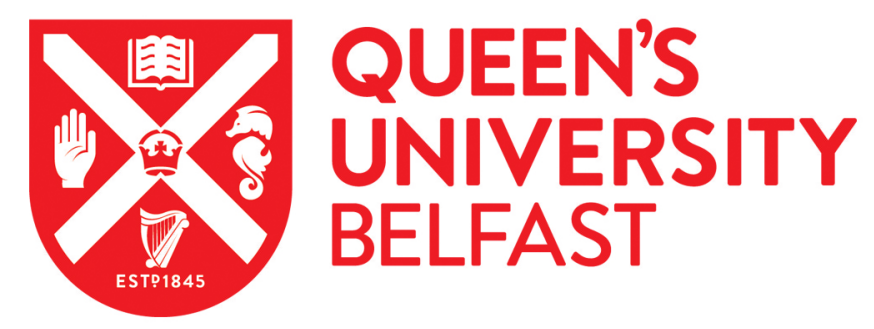

\title{
A Paradigm Shift in the Trophic Importance of Jellyfish?
}

Hays, G. C., Doyle, T. K., \& Houghton, J. D. R. (2018). A Paradigm Shift in the Trophic Importance of Jellyfish? Trends in Ecology \& Evolution, 33(11), 874-884. https://doi.org/10.1016/j.tree.2018.09.001

\section{Published in:}

Trends in Ecology \& Evolution

\section{Document Version:}

Peer reviewed version

\section{Queen's University Belfast - Research Portal:}

Link to publication record in Queen's University Belfast Research Portal

\section{Publisher rights}

Copyright 2018 Elsevier

This manuscript is distributed under a Creative Commons Attribution-NonCommercial-NoDerivs License

(https://creativecommons.org/licenses/by-nc-nd/4.0/), which permits distribution and reproduction for non-commercial purposes, provided the author and source are cited.

\section{General rights}

Copyright for the publications made accessible via the Queen's University Belfast Research Portal is retained by the author(s) and / or other copyright owners and it is a condition of accessing these publications that users recognise and abide by the legal requirements associated with these rights.

\section{Take down policy}

The Research Portal is Queen's institutional repository that provides access to Queen's research output. Every effort has been made to ensure that content in the Research Portal does not infringe any person's rights, or applicable UK laws. If you discover content in the Research Portal that you believe breaches copyright or violates any law, please contact openaccess@qub.ac.uk. 


\title{
A paradigm shift in the trophic importance of jellyfish ?
}

\author{
Graeme C. Hays ${ }^{1}$, Thomas K. Doyle ${ }^{2}$ and Jonathan D.R. Houghton ${ }^{3}$ \\ ${ }^{1}$ Centre for Integrative Ecology, Deakin University, Geelong, Australia \\ ${ }^{2}$ School of Biological, Earth and Environmental Sciences, Environmental Research Institute, University \\ College Cork, Ireland \\ ${ }^{3}$ School of Biological Sciences, Queen's University Belfast, Belfast, UK \\ Correspondence.g.hays@deakin.edu.au (G.C.Hays)
}

Keywords. jelly web; diet; ingestion rates; fasting endurance; salp; siphonophores; appendicularian

The last $\mathbf{3 0}$ years have seen several paradigm shifts in our understanding of how ocean ecosystems function. Now recent technological advances add to an overwhelming body of evidence for another paradigm shift in terms of the role of gelatinous plankton ("jellyfish") in marine food webs. Traditionally viewed as trophic dead ends, stable isotope analysis of predator tissues, animal-borne cameras and DNA analysis of faecal and gut samples (metabarcoding) are all indicating that many taxa routinely consume jellyfish. Despite their low energy density, the contribution of jellyfish to the energy budgets of predators may be much greater than assumed because of rapid digestion, low capture costs, availability and selective feeding on the more energy rich components.

Jellyfish as trophic dead ends: a "belly-full-of-jelly" ?

Gelatinous zooplankton, loosely termed "jellyfish", are a taxonomically diverse group including many cnidarians, such as scyphozoan jellyfish and siphonophores, ctenophores and also chordates such as salps, pyrosomes and appendicularians (Box 1, Figure 1). Jellyfish are ubiquitous in the World's oceans and can occur in very high densities in large blooms [1, 2]. For example, distinct coastal jellyfish hotspots can occur in coastal waters, such as large aggregations of the barrel jellyfish Rhizostoma octopus extending over tens of square kilometers, with individuals weighing as much as $30 \mathrm{~kg}$ [3]. Likewise, in oceanic waters, swarms of salps, each a few $\mathrm{cm}$ in size, have been recorded with densities as high as 700 individuals per $\mathrm{m}^{-3}$ over $1000 \mathrm{sm}^{2}[4,5]$. While it is well known that jellyfish can be voracious predators and so play important roles as consumers, they have historically often been viewed as trophic dead ends [6]. Underpinning this view is the generally low nutritional content of jellyfish (or at least the gelatinous 'bell'), meaning that large volumes need to be 
consumed for a predator to meet metabolic demands. For example, comparative energy densities have been reported of 0.10-0.18 kJ per g wet mass $^{-1}$ for scyphozoan jellyfish and 2.4-5.8 kJ per g wet mass $^{-1}$ for various fish species respectively [7]. Put simply, in this case a predator would need to eat about 25-30 times as much gelatinous tissue compared to fish to ingest the same energy content. A more recent review reiterates the low energy density of jellyfish on a wet weight basis [8].

Given the low energy density of jellyfish it has classically been argued that a diet of jellyfish would necessitate a predator carrying around a large "belly-full-of-jelly" which would lead to lower streamlining and reduce maneuverability, hence leading to higher susceptibility of that jelly-feeder to predation itself [6]. For this reason there is a long standing suggestion that two of the most wellknown consumers of jellyfish, the ocean sunfish (Mola mola) and the leatherback turtle (Dermochelys coriacea), are both massive. Both species weigh many $100 \mathrm{~s}$ of $\mathrm{kg}$ as adults, with their large size thought to confer protection against predation, even if these mega-vertebrates are slow swimming following a bout of feeding [6]. Observations of feeding and energy balance equations illustrate how these predators likely consume vast amounts of jellyfish in order to maintain energy balance. For example, by attaching a video camera system to the carapace of leatherback turtles it was estimated that adults, weighing around $450 \mathrm{~kg}$, foraging in summer off Nova Scotia consume an average of $330 \mathrm{~kg}$ jellyfish wet mass per day, equivalent to $73 \%$ of their body mass per day [9]. Aside from these specialist feeders of jellyfish it has been known for many decades that a range of species may occasionally consume jellyfish [10-13], but their contribution to the energy budget of ocean predators has been equivocal and has tended to be ignored [14].

\section{Old question, new methodologies: recent evidence for jellyfish consumption}

While evidence of predation on jellyfish is certainly not a new phenomenon [10-13], new technologies are revealing just how widespread consumption of jellyfish is among marine predators, including such charismatic taxa as tuna, albatrosses and penguins. Methodologies that are transforming our view of jellyfish as prey include stable isotope analysis (SIA) of the tissues of predators $[15,16]$, animal-borne cameras $[17,18]$ remotely operated vehicles (ROVs) $[19,20]$ and molecular analysis of stomach contents and faecal samples [21-24] (Box 2). As well as targeted consumption of jellyfish, in some cases jellyfish may be consumed incidentally when predators are targeting the small fish and crustaceans that often live in and around their bodies [25](Fig 1a). Additionally, jellyfish themselves are active predators of ocean plankton (including larval fishes) and so will concentrate prey within their oral arms and stomachs. So by consuming jellyfish, animals also 
profit from consuming the prey of the jellyfish themselves, i.e. jellyfish and their associated biota are consumed in a variety of ways.

Stable isotope analysis suggests that jellyfish most likely can form an important nutritional component of the diet for a range of fish species including Atlantic bumper (Chloroscombrus chrysurus), bluefin tuna (Thunnus thynnus), little tunny (Euthynnus alletteratus), spearfish (Tetrapturus belone) and swordfish (Xiphias gladius) [15]. Others have used SIA to show the importance of jellyfish for green sea turtles (Chelonia mydas) in some regions, a species traditionally thought to be mainly herbivorous when living in in coastal environments [16]. Likewise, cameras attached to four species of penguin have recently been shown consumption of scyphozoan jellyfish, salps, and ctenophores with jellyfish representing up to $42.4 \%$ of the prey capture events for some species [17]. Such empirical foraging data (encompassing prey encounter rate, selection, consumption and handling time) can open the door to field-based studies of optimal foraging via functional response [26]. This approach would drive a step-change in our understanding of jellyfish as prey allowing us to move beyond studies of tractable species under controlled conditions.

Likewise, molecular analysis (metabarcoding) can match minute quantities of DNA found in gut contents and or faecal (scat) samples to a range of potential prey items and has been used to show that for both sea birds and fish, jellyfish can be an important component of the diet [21-24]. For example in a recent study of two species of albatross across eight breeding sites in which $>1000$ scat samples were analyzed, scyphozoan jellyfish represented $20 \%$ of the food DNA sequences, second only in importance to bony fish ( $66 \%$ of food DNA sequences) and ahead of crustaceans ( $8 \%$ of food DNA sequences) [21]. Similarly, next generation sequencing has been used to determine the gut contents of the leptocephali larvae of the endangered European eel Anguilla anguilla in the Sargasso Sea [27]. With gelatinous zooplankton (mostly siphonophores) representing $76 \%$ of the DNA sequences detected, it is clear that leptocephali larvae have an apparent preference for consuming jellyfish.

While the use of remotely operated vehicles to quantity species diversity in the deep sea is well known, recent forays with remotely operated vehicle (ROVs) have revealed new predatorjellyfish interactions for little studied deep sea organisms but also for familiar surface associated species. For example, the elusive giant deep-sea octopus Haliphron atlanticus feeds on deep sea jellyfish [20]; and ROVs have been used to actively track sea turtles in situ; revealing predation on scyphozoan jellyfish, comb jellies and salps [19]. Furthermore, cameras deployed on the seabed have shown that jellyfish sinking to the seabed may be rapidly consumed by a range of benthic animals including fish, crabs, shrimps, amphipods and worms. For example, evidence from cameras suggests that dead jellyfish represent a significant component of the diet of commercially exploited lobster 
Nephrops norvegicus in Norwegian fjords [28,29]. Likewise high levels of consumption of jellyfish by several species of benthic fish in the NW Atlantic suggests that blooms of jellyfish provide important surges of food for the benthic community [30]. Direct observation and filming by divers have also been reported showing a range of species consuming jellyfish, including fish and turtles, and as with other camera observation allow ingestion rates of jellyfish to be estimated [31,32]. Even more opportunistically, mallard ducks (Anas platyrhynchos) have been photographed at the surface feeding on extensive blooms of the hydrozoan Velella velella which illustrates that the trophic pathways of jellyfish can even extend beyond the marine environment [33]. Recent work is also shedding new light on how pelagic invertebrates, many themselves jellyfish, will routinely feed on jellyfish [34-36], supporting a recent review of benthic scavengers and predators of jellyfish which collated many historical and some recent records of invertebrates feeding on jellyfish, mostly anemones, decapod crustaceans and echinoderms [37]. A parasitic variation on this theme is the use of jellyfish as reproductive habitat by hyperiid amphipods, with bell tissue serving as food for both adults and emergent offspring [38].

Importantly these various studies showing consumption of jellyfish have taken place throughout the world oceans and have involved a range of different types of jellyfish and predator (Fig 2a). So the picture emerging from range of methodologies is that jellyfish may often feature highly in the diets of a range of marine predators, that jellyfish may be actively targeted and that they are not simply ingested as bycatch and that sometimes jellyfish may be making an important nutritional contribution to the diet. Furthermore changing ocean conditions may sometimes favour the importance of jellyfish as food. For example, using gut content analysis to assess the diet of several fish species in the Pacific over a 15 year period, it has recently been shown that jellyfish were consumed in much higher quantities in warmer years with the conclusion that predators may feed on jellyfish when other food sources are unavailable [39]. Similarly the importance of ctenophores in the diet of Atlantic cod (Gadus morhua) has grown over the last 30 years [40].

Interestingly these new methodologies are also changing our understanding of the diet of animals previously assumed to feed almost entirely on jellyfish. For example, the ocean sunfish, Mola mola, has long been though to feed on jellyfish in an almost obligate manner. However, in recent years both DNA barcoding as well as SIA have both revealed that ocean sunfish can have a far more cosmopolitan diet [41-43], with an apparent shift towards a more gelatinous diet in larger individuals [44].

\section{Blending old and new evidence: can marine animals survive on a diet of jellyfish?}


While the modern techniques are increasingly revealing the presence of jellyfish in the diets of marine predators, it may be informative to turn to some of the classic older literature to assess the potential relative importance of this prey group to energy budgets. At first glance it would appear that the low energy density of jellyfish would likely mean they are simply ingested incidentally and other prey, such as fish and crustaceans, will contribute the bulk of the energy requirements of predators. However, in a classic set of experiments performed almost 20 years ago it was shown digestion rates when feeding on jellyfish could be $20 \times$ faster than for shrimp [45](Figure 2b). Put simply, the lower energy density of jellyfish may be counterbalanced by the speed with which they can be digested, so that it may be that jellyfish can actually provide comparable rates of energy acquisition to predators than feeding on fish or crustaceans.

Due to this quick digestion of jellyfish they will also tend to be under-represented in gut content analysis. However, such traditional approaches may still indicate very recent feeding on jellyfish and so complement results emerging from other methodologies. For example, a recent analysis of 69,000 stomachs showed that 39 of 107 species of fish consumed jellyfish of which 23 fish species were previously undocumented as jellyfish consumers [46]. This study also showed how visual analysis of stomach samples can still deliver important information on dietary importance of jellyfish, particularly when fish stomachs and prey are examined immediately after a fish are collected to alleviate concerns over the degradation of jellyfish in stomachs caused by formalin or ethanol preservation or rapid digestion.

In addition to their rapid digestion, the dietary value of jellyfish is further enhanced because they (i) may be extremely abundant when encountered within blooms, (ii) do not move fast and (iii) many jellyfish taxa have extremely fast growth rates, providing three reasons for why the energy expended per unit capture when feeding on jellyfish is likely, at certain times, to be much lower/or strategically beneficial when compared to feeding on fish or other prey items which need to be actively pursued or found. For example, in oligotrophic waters of the Straits of Florida, gut content analysis and concurrent plankton tows revealed that the larvae of three species of tuna fed almost exclusively on appendicularians before they switched to piscivory [47]. Whilst it has long been known that pleuronectiform larvae need to feed on appendicularians, [48], this new work suggests that tuna larvae exploit a previously unrecognised 'nutritional loophole' [47]. Specifically, they obtain energy directly from the microbial loop and therefore, with their extremely fast growth rates, offer a relatively large consistent food source in an oligotrophic environment [47]. Jellyfish may also be important as food for larval fish in tropical environments [49]. One possibility is that by consuming jellyfish, larval reef fish may be able to extend their larval duration giving them more chance to find suitable reef sites for settlement. 
Camera footage has also shown that some predators, such as the ocean sunfish, may feed selectively on specific tissues within larger jellyfish; for example, tending to consume the energy rich gonads and oral arms of scyphozoan jellyfish and ignoring the lower energy density swimming bell $[31,50]$. These different components of jellyfish may differ in their energy densities by five-fold [7] and so by consuming energy rich components, marine predators can substantially improve their rate of energy ingestion. In accord with this suggestion that when jellyfish are abundant they can satisfy the energy demands of a range of predators, SIA has been used recently to show that for small fish living under the shelter of jellyfish; i.e. where jellyfish as food is essentially freely available (e.g. see Fig 1a), jellyfish tissue contributed $90 \%$ of the assimilated energy [51]. Future investigations should also probe the dietary 'value' of jellyfish beyond energetic gain. For example, jellyfish are typically rich in type II collagen (up to $46.4 \%$ dry mass), which is a major component of connective tissues in vertebrates such as cartilage, and a range of fatty acids and lipids [52]. Indeed, medical and pharmaceutical industries are harvesting type II collagen from jellyfish for a host of products (e.g. [53], so this idea that marine predators may likewise benefit from consuming jellyfish collagen may not be unfounded.

\section{Constraints to being a specialist versus generalist predator of jellyfish?}

The evidence that a range of marine predators will feed on jellyfish challenges the view that the need to have a "belly-full-of-jelly" limits the number of jelly-feeders. Fast pursuit predators such as penguins and tuna will likely avoid having such pitfalls even when feeding on jellyfish due to rapid digestion. Hence we need to look for alternative explanation for why the leatherback turtle, that is thought to feed almost exclusively on jellyfish, is so large. The answer may be linked, to the fact that while jellyfish are ubiquitous in the World's oceans, they are only occasionally found in very high bloom densities [54]. So feeding only on jellyfish will likely mean that there are long periods of nearfasting between encounters with blooms. Tracking data for leatherback turtle supports this idea with individuals followed for up to one year showing evidence of feeding in jellyfish blooms only for about $30 \%$ of the time [55]. So long fasting endurance may be the key requirement for a predator to feed only on jellyfish. Adult sea turtles likely have a very long fasting endurance, probably $>6$ months, linked to their low mass-specific metabolic rate resulting from both its ectothermy and large size [56]. Other marine predators that are smaller (e.g. small fish) and/or endothermic (e.g. tunas and marine birds) will have higher mass specific metabolic rates and hence more limited fasting endurance. It is most probably this limited fasting endurance that explains why most of marine predators found to consume jellyfish, likely only feed opportunistically or only at specific life stages 
(e.g. tuna and eel larvae, adult sunfish), rather than exclusively, on jellyfish. Laboratory trials support his view that fish may feed opportunistically on jellyfish $[57,58]$.

One further issue with high levels of jellyfish consumption is that predators will also ingest large volumes of salt which needs to be removed from their bodies. Marine predators have specialized physiologies for salt removal, such as salt glands found in leatherback turtles and marine birds $[59,60]$. For example, though such physiological adaptations it is estimated that a $450 \mathrm{~kg}$ leatherback turtle can produce about 6-9 litres of lachrymal secretion (salty tears) per hour enabling the consumption of $80 \%$ body mass day $^{-1}$ of jellyfish [59]. Such rates of ingestion cannot be extrapolated to all marine predators as the vast majority lack such a capacity to process excess salt, prompting studies to examine the link between anatomy, physiology and rate of jellyfish ingestion.

\section{Concluding remarks and future directions}

There is now overwhelming evidence suggesting that jellyfish cannot simply be ignored as trophic dead ends but rather are opportunistically consumed by a wide range of marine predators. Such trophic pathways reflect the abundance, aggregation and seasonality of jellyfish and challenge the intuitive view that the reward from feeding on jellyfish would be outstripped by the effort. Indeed, when considering selective foraging on gonadal tissue, for example, the energetic reward and accessibility of the resource is most certainly worthy of a predator's attention. However, our understanding of jellyfish dietary 'value' should in time extend beyond energetic gain, to encompass more nuanced physiological requirements (e.g. the ingestion of collagen or lipids). These findings may be particularly important given that jellyfish compose a large fraction of the pelagic biomass and, in some regions have oscillated or increased significantly in their abundance $[61,62]$ over recent decades; sometimes linked to climate change or more direct forms of anthropogenic disturbance $[1,62]$. It is clear that a lot more consideration needs to be given to parameterizing the role of jellyfish in marine ecosystems $(63,64)$.

\section{Author Contributions}

G.C.H. conceived the study and led the writing with input from T.K.D and J.D.R.H 


\section{References}

1. Richardson, A.J. et al. (2009) The jellyfish joyride: Causes, consequences and management responses to a more gelatinous future. Trends Ecol. Evol. 24, 312-322

2. Schaub. J. et al. (2018) Using unmanned aerial vehicles (UAVs) to measure jellyfish aggregations. Mar. Ecol. Prog. Ser. 591, 29-36

3. Houghton, J.D.R. et al. (2006) Developing a simple, rapid method for identifying and monitoring jellyfish aggregations from the air. Mar. Ecol. Prog. Ser. 314, 159-170

4. Bathmann, U.V. (1988) Mass occurrence of Salpa fusiformis in the spring of 1984 off Ireland: implications for sedimentation processes. Mar. Biol. 97, 127-135

5. Smith Jr, K.L. et al. (2014) Large salp bloom export from the upper ocean and benthic community response in the abyssal northeast Pacific: Day to week resolution. Limnol. Oceanogr. 59, 745-757

6. Verity, P.G. and Smetacek, V. (1996) Organism life cycles, predation, and the structure of marine pelagic ecosystems. Mar. Ecol. Prog. Ser. 130, 277-293

7. Doyle, T.K. et al. (2007) The energy density of jellyfish: estimates from bomb-calorimetry and proximate-consumption. J. Exp. Mar. Biol. Ecol. 343, 239-252

8. Schaafsma, F.L. et al. (2018) Review: the energetic value of zooplankton and nekton species of the Southern Ocean. Mar. Biol. 165:129

9. Heaslip, S.G. et al. (2012) Jellyfish support high energy intake of leatherback sea turtles (Dermochelys coriacea): Video evidence from animal-borne cameras. PLoS ONE 7: e33259

10. Arai, M.N. (2005) Predation on pelagic coelenterates: a review. J. Mar. Biol. Ass. UK 85, 523-536

11. McCanch, N.V. and McCanch, M. (1996) Fulmars feeding on jellyfish. British Birds 89, 569-570

12. Purcell, J.E. et al. (2005) A review of appendicularians as prey of fish and invertebrate predators. In Response of marine ecosystems to global change: Ecological impact of appendicularians (Gorsky, G., Youngbluth, M.J. and Deibel, D., eds.), pp. 359-435, Contemporary Publishing International

13. Harbison, G.R. (1998) The parasites and predators of Thaliacea. In The Biology of Pelagic Tunicates (Bone, Q., ed.), pp.187-214, Oxford University Press

14. Hamilton, G. (2016) The secret lives of jellyfish: long regarded as minor players in ocean ecology, jellyfish are actually important parts of the marine food webs. Nature 531, 432-435

15. Cardona, L. et al. (2012) Massive consumption of gelatinous plankton by Mediterranean apex predators. PLOS ONE 7: e31329

16. González Carman, V.G. et al. (2014) A jellyfish diet for the herbivorous green turtle Chelonia mydas in the temperate SW Atlantic. Mar. Biol. 161, 339-349 
17. Thiebot, J-B et al. (2017) Jellyfish and other gelata as food for four penguin species - insights from predator-borne videos. Front. Ecol. Environ. 15, 437-441

18. Thiebot, J.B. et al. (2016) On the significance of Antarctic jellyfish as food for Adelie penguins, as revealed by video loggers. Mar. Biol. 163, 108

19. Smolowitz, R.J. et al. (2015) Using a remotely operated vehicle (ROV) to observe loggerhead sea turtle (Caretta caretta) behavior on foraging grounds off the mid-Atlantic United States. J. Exp. Mar. Biol. Ecol. 471, 84-91

20. Hoving, H.J.T. and Haddock, S.H.D. (2017) The giant deep-sea octopus Haliphron atlanticus forages on gelatinous fauna. Sci. Rep. 7, 44952

21. McInnes, J.C. et al. (2017) High occurrence of jellyfish predation by black-browed and Campbell albatross identified by DNA metabarcoding. Mol. Ecol. 26, 4831-4845

22. Lamb, P.D. et al. (2017). Jellyfish on the menu: mtDNA assay reveals scyphozoan predation in the Irish Sea. R. Soc. Open Sci. 4, 171421

23. Jarman, S. N. et al. (2013) Adelie penguin population diet monitoring by analysis of food DNA in scats. PLOS ONE 8, e82227

24. Mclnnes, J.C. et al. (2016) Simultaneous DNA-based diet analysis of breeding, nonbreeding and chick Adelie penguins. R. Soc. Open Sci. 3, 150443

25. Sato, N.N. et al. (2015) The jellyfish buffet: jellyfish enhance seabird foraging opportunities by concentrating prey. Biol. Lett. 11, 20150358

26. Dick, J.T.A et al. (2013) Ecological impacts of an invasive predator explained and predicted by functional responses. Biol. Inv. 15, 837-846

27. Ayala, D.J. et al. (2018) Gelatinous plankton is important in the diet of European eel (Anguilla anguilla) larvae in the Sargasso Sea. Sci. Rep. 8, 6156

28. Sweetman, A.K. et al. (2014) Rapid scavenging of jellyfish carcasses reveals the importance of gelatinous material to deep-sea food webs. Proc. R. Soc. B 281, 20142210

29. Dunlop, K.M. et al. (2017) Direct evidence of an efficient energy transfer pathway from jellyfish carcasses to a commercially important deep-water species. Sci. Rep. 7: 17455

30. Smith, B.E. et al. (2016) Bloom or bust: Synchrony in jellyfish abundance, fish consumption, benthic scavenger abundance, and environmental drivers across a continental shelf. Fish. Oceanogr. 25, 500-514

31. Milisenda, G. et al. (2014) Jellyfish as prey: frequency of predation and selective foraging of Boops boops (Vertebrata, Actinopterygii) on the Mauve Stinger Pelagia noctiluca (Cnidaria, Scyphozoa). PLoS ONE 9, e94600 
32. Fossette, S. et al. (2012) Does prey size matter? Novel observations of feeding in the leatherback turtle (Dermochelys coriacea) allow a test of predator-prey size relationships. Biol. Lett. 8, 351354

33. Phillips, N. et al. (2017) Quacks snack on smacks: mallard ducks (Anas platyrhynchos) observed feeding on hydrozoans (Velella velella). Plankton Benthos Res. 12, 143-144

34. Bayha, K.M. et al. (2012) Predation potential of the jellyfish Drymonema larsoni Bayha \& Dawson (Scyphozoa: Drymonematidae) on the moon jellyfish Aurelia sp. in the northern Gulf of Mexico. Hydrobiologia 690, 189-197

35. Wakabayashi, K. et al. (2012) Predation by the phyllosoma larva of Ibacus novemdentatus on various kinds of venomous jellyfish. Biol. Bull. 222, 1-5

36. O'Rorke, R. et al. (2012) Determining the diet of larvae of western rock lobster (Panulirus cygnus) using high-throughput DNA sequencing techniques. PLOS ONE 7, e42757

37. Ates, R.M.L. (2017) Benthic scavengers and predators of jellyfish, material for a review. Plankton Benthos Res. 12, 71-77

38. Fleming, N.E.C. et al. (2014) Scyphozoan jellyfish provide short-term reproductive habitat for hyperiid amphipods in a temperate near-shore environment. Mar. Ecol. Prog. Ser. 510, 229-240

39. Brodeur, R.D. et al. (2018) Effects of warming ocean conditions on feeding ecology of small pelagic fishes in a coastal upwelling ecosystem: a shift to gelatinous food sources. Mar. Ecol. Prog. Ser. https://doi.org/10.3354/meps12497

40. Eriksen, E. et al. (2017) Cod diet as an indicator of Ctenophora abundance dynamics in the Barents Sea. Mar. Ecol. Prog. Ser. https://doi.org/10.3354/meps12199

41. Sousa, L.L. et al. (2016) DNA barcoding identifies a cosmopolitan diet in the ocean sunfish. Sci. Rep. 6, 28762

42. Syväranta, J. et al. (2011) Stable isotopes challenge the perception of ocean sunfish Mola mola as obligate jellyfish predators. J. Fish Biol. 80, 225-231

43. Harrod, C. et al. (2013) Reply to Logan \& Dodge: 'Stable isotopes challenge the perception of ocean sunfish Mola mola as obligate jellyfish predators'. J. Fish Biol. 82, 10-16

44. Nakamura, I. and Sato, K. (2014) Ontogenetic shift in foraging habit of ocean sunfish Mola mola from dietary and behavioral studies. Mar. Biol. 161, 1263-1273

45. Arai, M.N. et al. (2003) Digestion of pelagic Ctenophora and Cnidaria by fish. Can. J. Fish. Aquat. Sci. $60,825-829$

46. Diaz-Briz, L. et al. (2017) Gelatinous zooplankton (ctenophores, salps and medusae): an important food resource of fishes in the temperate SW Atlantic Ocean. Mar. Biol. Res. 13, 630644 
47. Llopiz, J.K. et al. (2010) Distinctions in the diets and distributions of larval tunas and the important role of appendicularians. Limnol. Oceanogr. 55 983-996

48. Last, J.M. (1978) The food of four species of pleuronectiform larvae in the eastern English Channel and southern North Sea. Mar. Biol. 45, 359-368

49. Sampey, A. et al. (2007). Glimpse into guts: overview of the feeding of larvae of tropical shorefishes. Mar. Ecol. Prog. Ser. 339: 243-257

50. Nakamura, l. et al. (2015) Ocean sunfish rewarm at the surface after deep excursions to forage for siphonophores. J. Anim. Ecol. 84, 590-603

51. D'Ambra, l. et al. (2015) Fish rely on scyphozoan hosts as a primary food source: evidence from stable isotope analysis. Mar. Biol. 162, 247-252

52. Nagai, T. et al. (1999) Collagen of edible jellyfish exumbrella. J. Sci. Food. Agric. 79, 855-858

53. Hoyer, B. et al. (2014) Jellyfish collagen scaffolds for cartilage tissue engineering. Acta Biomaterialia 10, 883-892

54. Lilley, M.K.S et al. (2009) Distribution, extent of inter-annual variability and diet of the bloomforming jellyfish Rhizostoma in European waters. J. Mar. Biol. Assoc. U.K. 98, 39-48

55. Bailey, H. et al. (2012) Movement patterns for a critically endangered species, the leatherback turtle (Dermochelys coriacea), linked to foraging success and population status. PLOS ONE 7, e36401

56. Hays, G.C. and Scott, R. (2013) Global patterns for upper ceilings on migration distance in sea turtles and comparisons with fish, birds and mammals. Funct. Ecol. 27, 748-756

57. Marques, R. et al. (2016) Jellyfish as an alternative source of food for opportunistic fishes. J. Exp. Mar. Biol. Ecol. 485, 1-7

58. Miyajima-Taga, Y. et al. (2016) Ontogenetic changes in the predator-prey interactions between threadsail filefish and moon jellyfish. Hydrobiologia 772, 175-187

59. Davenport, J. (2017) Crying a river: how much salt-laden jelly can a leatherback turtle really eat ? J. Exp. Biol. 220, 1737-1744

60. Ostrom, P.H. et al. (2014) Unexpected hydrogen isotope variation in oceanic pelagic seabirds. Oecologia 175, 1227-1235

61. Condon R.H. et al. (2013) Recurrent jellyfish blooms are a consequence of global oscillations. Proc. Natl. Acad. Sci. U.S.A. 110, 1000-1005

62. Duarte, C.M. et al. (2013) Is global ocean sprawl a cause of jellyfish blooms? Front. Ecol. Environ. $11,91-97$ 
63. Brodeur, R.D. et al. (2016) Ecological and economic consequences of ignoring jellyfish: A plea for increased monitoring of ecosystems. Fisheries 41, 630-637

64. Aubert, A. (2018) No more reason for ignoring gelatinous zooplankton in ecosystem assessment and marine management: Concrete cost-effective methodology during routine fishery trawl surveys. Mar. Policy 89, 100-108

65. Pauly, D. et al. (2009) Jellyfish in ecosystems, online databases and ecosystem models. Hydrobiologia $616,67-85$

66. Doyle, T.K. et al. (2014) Ecological and Societal Benefits of Jellyfish. In: Pitt K., Lucas C. (eds) Jellyfish Blooms. Springer, Dordrecht. pp 105-217

67. Fossette, S. et al. (2015) Current-Oriented swimming by jellyfish and its role in bloom maintenance. Curr. Biol. 25, 342-347

68. Schlaefer, J.A. et al. (2018) Swimming behaviour can maintain localised jellyfish (Chironex fleckeri: Cubozoa) populations. Mar. Ecol. Prog. Ser. 591, 287-302

69. Henschke, N. et al. (2016) Rethinking the Role of Salps in the Ocean. Trends Ecol. Evol. 31, 720733

70. Li, K.Z. et al. (2016) High abundance of salps in the coastal Gulf of Alaska during 2011: A first record of bloom occurrence for the northern Gulf. Deep-Sea Res. Part I 132, 136-145

71. Suprenand, P.M. et al. (2017) Trophodynamic effects of climate change-induced alterations to primary production along the western Antarctic Peninsula. Mar. Ecol. Prog. Ser. 569, 37-54

72. Steinberg, D.K. et al. (2015) Long-term (1993-2013) changes in macrozooplankton off the Western Antarctic Peninsula. Deep-Sea-Res. Part I. 101, 54-70

73. Choy, C.A. et al. (2017) Deep pelagic food web structure as revealed by in situ feeding observations. Proc. R. Soc. B 284: 20172116

74. Phillips, D.L. et al. (2014) Best practices for use of stable isotope mixing models in food-web studies. Can. J. Zool. 92, 823-835

75. McInnes, J.C. et al. (2016) A review of methods used to analyse albatross diets-assessing priorities across their range. ICES J. Mar. Sci. 73, 2125-2137

76. Parnell, A.C. et al. (2010) Source partioning using stable isotopes: coping with too much variation. PLOS ONE 5, e9672

77. Chiaradia, A. et al. (2016). Stable isotopes $(\delta 13 C, \delta 15 N)$ combined with conventional dietary approaches reveal plasticity in central-place foraging behavior of little penguins Eudyptula minor. Front. Ecol. Evol. 3, 154

78. Nielsen, J.M. et al. (2018) Diet tracing in ecology: Method comparison and selection. Methods Ecol. Evol. 9, 278-291 
79. Pitt, K.A. et al. (2009) Stable isotope and fatty acid tracers in energy and nutrient studies of jellyfish: a review. Hydrobiologia 616, 119-132

80. Moll, R.J. et al. (2007) A new 'view' of ecology and conservation through animal-borne video systems. Trends Ecol. Evol. 22, 660-668

81. Nishizawa, B. et al. (2018) Albatross-borne loggers show feeding on deep-sea squids: implications for the study of squid distributions. Mar. Ecol. Prog. Ser. 592, 257-265

82. Pagano, A.M. et al. (2018) High-energy, high-fat lifestyle challenges an Arctic apex predator, the polar bear. Science 359, 568-572

83. Dahl, K.A. et al. (2017) DNA barcoding significantly improves resolution of invasive lionfish diet in the Northern Gulf of Mexico. Biol. Invasions 19, 1917-1933

84. Kartzinel, T.R. et al. (2015) DNA metabarcoding illuminates dietary niche partitioning by African large herbivores. Proc. Natl. Acad. Sci. U.S.A. 112, 8019-8024

85. Schneider, S. et al. (2017) Selective plant foraging and the top-down suppression of native diversity in a restored prairie. J. Appl. Ecol. 54, 1496-1504

86. Thomas, A.C. et al. (2016) Quantitative DNA metabarcoding: improved estimates of species proportional biomass using correction factors derived from control material. Mol. Ecol. Res. 16, 714-726

87. McInnes, J.C. et al. (2017) Optimised scat collection protocols for dietary DNA metabarcoding in vertebrates. Methods Ecol. Evol. 8, 192-202

88. Arkhipkin, A. and Laptikhovsky, V. (2013) From gelatinous to muscle food chain: rock cod Patagonotothen ramsayi recycles coelenterate and tunicate resources on the Patagonian Shelf. J. Fish. Biol. 83, 1210-1220

89. Archer, S.K. et al. (2018) Pyrosome consumption by benthic organisms during blooms in the northeast Pacific and Gulf of Mexico. Ecology 99, 981-984

\section{Box 1. What are jellyfish?}

The term "jellyfish" is often considered to be synonymous with the phylum Cnidaria and the class Scyphozoa which are the traditional bell-shaped pulsing gelatinous animals seen across the World's oceans that vary in size from a few $\mathrm{cm}$ up to individuals that may weigh many tens of kg [66] (Fig. 1). While generally considered to be zooplankton, i.e. animals that drift with ocean currents, the larger scyphozoans are strong swimmers and can move independently of currents $[67,68]$. Scyphozoan jellyfish capture prey by pulsing their bell which entrains and transports prey past their tentacles or oral arms that are lined with stinging nematocysts. In addition to scyphozoans, more broadly, the 
term "jellyfish" can encompass a wide range of other gelatinous taxa [66]. Within the Cnidaria there is also the class Hydrozoa that includes the hydromedusae such as Aequorea spp. and the colonial siphonophores, some of which may be several meters long such as Apolemia uvaria. The phylum Ctenophora are also called comb jellies or sea gooseberries and move themselves by the sequential beating of cilia that are located in distinct bands that run around their bodies. Ctenophores catch their plankton prey using extendable tentacles containing sticky cells called colloblasts that ensnare prey or some generate feeding currents that entrain prey. Other gelatinous marine animals, unrelated to the cnidarians and ctenophores, are in the phylum Chordata, namely, the salps, doliolids, pyrosomes and appendicularians [69]. Individual salps and doliolids are barrel shaped and range in size from a few $\mathrm{mm}$ and up to a many $\mathrm{cm}$ and filter water to obtain their microscopic food. They may form long colonial chains several metres long and, like other gelatinous plankton, may occur in very high densities [70] and show long term changes in abundance linked to climate $[71,72]$. Similarly pyrosomes may form colonies several metres in length, with thousands of individuals, termed zooids, embedded in a common gelatinous matrix that joins the colony. Across this diverse range of taxa, jellyfish often have complex life cycles which vary with taxonomy, some remaining in the plankton throughout their lives, such as the ctenophores, while others may have life stages on the seabed. High density mono-specific blooms of jellyfish occur around the world's oceans, but often there may be many species in one area that form a complex part of a complex food web known as the "jelly-web" [73].

\section{Box 2. Recently used methodologies for assessing dietary importance of jellyfish}

\section{Stable isotope analysis}

Stable isotope analysis (SIA) has been used for many decades to assess animal diets $[74,75]$ and recently there has been increased use of this approach for looking at the dietary important of jellyfish; driven partly by advances in analysis that yield far greater resolution beyond trophic level (e.g. Bayesian mixing models [76]). SIA is based on the fact that the isotopic composition of an animal's tissues is influenced by that of its prey, with typically isotopic enrichment of the lighter isotope occurring between prey and predator. Most commonly stable isotope of nitrogen and carbon are used in food web analysis $[77,78]$. The approach needs information on the isotopic composition of the potential prey items. Once of the advantages of this approach is that different tissues have different isotopic turnover rates and so their SI compositions integrate different timewindows of feeding. For example, blood has a high turnover rate and so will typically reflect the 
feeding history of a few weeks prior to blood sampling, while muscle has a slower turnover rate and so reflects the feeding history over several months. However sometimes there is uncertainty in assessing diet with this approach. For example, the isotopic signatures of all potential prey items may not characterized and when using only two isotopes an ambiguous picture of an animal's diet may sometimes be obtained [79].

\section{Animal borne cameras}

Some of the first camera systems attached to marine animals were large analogue devices and so tended to be deployed on large animals included various marine mammals such as seals and whales. However, over the last two decades there has been a massive reduction in the size of cameras and so the ability to equip much smaller taxa. For example, cameras as small as $15 \mathrm{~g}$ have now been attached to penguins and murres/guillemots $[18,25]$. These devices have revealed a wealth of information on foraging behaviour of a range of taxa including penguins, turtles, and sharks [80-82]. The method allows individual prey capture events to be identified so that estimates of ingestion rates are possible. Furthermore, it may sometimes be possible to identify whether marine predators are feeding selectively on certain part of their prey. Limitations of technique are that typically only a few hours of video recording are possible on each deployment and devices need to be recovered for data download.

\section{DNA metabarcoding}

DNA metabarcoding is now being widely used to examine the diets of species across terrestrial and aquatic systems [83-85]. The technique is based around the fact that, while prey items in the gut and faeces may not be recognizable under microscopic examination, there is still DNA present from the different prey. Metabarcoding targets regions of DNA (barcodes) that have enough variability to distinguish different taxonomic groups, with Next Generation Sequencing allowing rapid processing of large number of samples [86]. As with SIA, DNA metabarcoding needs a good range of reference DNA profiles that encompasses as many of the potential prey items as possible. From each analysed sample the presence or absence of different prey taxa is obtained along with the relative abundance of DNA from different taxa. The latter value, the Relative Read Abundance (RRA), may provide a proxy for the relative proportion of different taxa in the diet, assuming that different taxa are digested to the same extent and at the same speed, which may not necessarily be the case when comparing, for example, digestion of jellyfish versus fish. The approach works well when faecal samples are easy to collect, for example with marine birds that return to land to roost or provision a 
chick [87]. However, for many other marine animals that remain at sea continuously, such as fish, collecting fecal samples is not so straightforward.

\section{Figure legends}

Figure 1. Variety of jellyfish in the ocean. There are a broad range of jellyfish in the oceans. (A) Scyphozoan jellyfish such the compass jellyfish (Chrysaora hysoscella) pictured often have small fish and/or crustaceans (amphipods) sheltering among the tentacles and oral arms. (B) Jellyfish can occur in extremely high densities such this bloom of moon jellyfish (Aurelia aurita) where each individual pictured measures $10-20 \mathrm{~cm}$ across. (C) Some jellyfish are very large such as the barrel jellyfish pictured (Rhizostoma octopus). This barrel jellyfish is shown minus the swimming bell so that only the stomach, gonads and oral arms are shown. (D) Other jellyfish are much smaller such as the ctenophore pictured (Pleurobrachia pileus) which measured about $2 \mathrm{~cm}$ across. Reproduced, with permission, from John Collins (A), Michelle Cronin (B), Tom Doyle (C), and Nigel Motyer (D).

Figure 2. Jellyfish on the menu worldwide. (A) In recent years a range of studies, using a variety of techniques such as stable isotope analysis of predator tissues, animal-borne cameras, remotely operated vehicles and molecular analysis of stomach contents and faecal samples, have shown that a broad range of marine predators including fish (including larvae), birds, green turtles and various invertebrates including octopus, holothurians (sea cucumbers) crabs and amphipods (including larvae) frequently feed on jellyfish. These approaches have also increased our knowledge of a predators previously well known to feed on jellyfish such as leatherback turtles and ocean sunfish. Pictured are illustrative examples of this breadth of recent work showing the general location of some of these studies and taxa shown to consume jellyfish illustrated schematically as flying sea birds [21], penguins $[17,18,23,24$, fish including fish larvae $[15,22,27,31,51,88]$, turtles $[9,16,32]$, crab [28,89], rock lobster larvae [36] and sea cucumber [5]. (B) Widespread consumption of jellyfish may be facilitated by their rapid digestion which helps to counterbalance their low energy density. Pictured experimental results showing speeds of digestion for chum salmon (Oncorhynchus keta) fed the ctenophore Pleurobrachia bachei and the hydromedusa Aequorea victoria versus shrimp (Pandalus sp.)(modified from 45). 
Figure 3. Encountering jellyfish blooms and fasting endurance. A leatherback turtle feeding in a dense bloom of the jellyfish (Linuche unguiculata) in the Solomon Islands [32]. While many marine predators opportunistically on jellyfish, adult leatherback turtles are unique in feeding solely on jellyfish. The long fasting endurance of adult leatherback means they can survive long periods, probably sometimes many months, between encounters with dense jellyfish blooms. Other marine predators with more limited fasting endurance, e.g. birds and small fish, feed opportunistically on jellyfish but switch to other prey depending on local prey availability. Reproduced, with permission, from Andrew Lewis. 